\title{
Wood frame house construction project in Mexico
}

\author{
Proyecto de construcción de una casa de madera tipo en México
}

\author{
Oscar Filio Reynoso (Main Author) \\ División de Ciencias Forestales \\ Universidad Autónoma Chapingo (Mexico) \\ oafr2003@hotmail.com
}

Amparo Borja de la Rosa (CorrespondingAuthor)

Universidad Autónoma Chapingo (Mexico)

aborja@correo.chapingo.mx

Mario Fuentes Salinas

Universidad Autónoma Chapingo (Mexico)

mariofusa@yahoo.com.mx

Alejandro Corona Ambriz

Universidad Autónoma Chapingo (Mexico)

ambrizcor@yahoo.com.mx

\author{
Manuscript Code: 775 \\ Date of Acceptance/Reception: 15.04.2017/26.05.2016 \\ DOI: 10.7764/RDLC.16.2.307
}

\section{Abstract}

Building wood frame houses is viewed as an excellent alternative to meet the growing demand for housing in Mexico. The aim was to design a pinewood house construction project, based on the stud structural system, to show how to proceed when building a particular housing model. The methodology is based on RCDF-2004, NTCRCDF-2004, ONNCCE S.C. Mexican standards and construction manuals. The blueprints, area and volume were derived using the AutoCAD 2010 program. Pinewood at MC $\leq 18 \%$, preserved with CCA (chromated copper arsenate) salts and graded with the "Class A" industrial rule was considered. Studs were placed every 24 " and plywood boards were used as bracing. As a result, a one-story dwelling with a gable roof and $74 \mathrm{~m}^{2}$ of living space was designed; the construction sequence, from the foundation (slab, chain and concrete footings) to the application of finishes and coverings (mortar and asphalt shingles), was performed. It is concluded that it is possible to properly design a wood frame house by following the recommendations and technical specifications in regulations, standards and manuals, thereby making it a practical alternative in housing construction.

Key words: stud, wood frame housing, wood construction.

\section{Resumen}

La construcción de casas de madera con el sistema constructivo pies derechos, se considera una excelente alternativa ante la creciente demanda de vivienda en México. El objetivo fue realizar el proyecto constructivo de una casa de madera de pino, basado en el sistema estructural pies derechos, para mostrar la forma de proceder al considerar construir un modelo de vivienda en particular. La metodología está fundamentada en el RCDF-2004, NTCRCDF -2004, normas mexicanas del ONNCCE S.C. y manuales de construcción. Los planos, área y volumen se realizaron con el programa AutoCAD 2010. Se contempló madera de pino a un $\mathrm{CH} \leq 18 \%$, preservada con sales CCA (Arseniato de cobre cromatado), clasificada con la regla industrial "Clase A". Se colocaron pies derechos a cada 24 " y tableros contrachapados como arriostramiento. Como resultado, se diseñó una vivienda de un piso, con techo a dos aguas y un espacio habitable de $74 \mathrm{~m}^{2}$; se realizó la secuencia constructiva iniciando desde la cimentación (losa, cadena y zapatas de concreto), hasta la aplicación de acabados y recubrimientos (mortero y teja asfáltica). Se concluye que es posible diseñar correctamente una vivienda de madera siguiendo las recomendaciones y especificaciones técnicas de reglamentos, normas y manuales, para considerarla como una alternativa en la construcción de viviendas

Palabras clave: Pie derecho, vivienda de madera, construcción con madera.

Due to the growing demand for housing in recent years, the light wood frame construction system is viewed as an excellent alternative for building homes with wood in Mexico.

It is currently the most widely used system because it is simple and allows high degrees of prefabrication and fast assembly. About $70-80 \%$ of buildings constructed in Canada, the United States, Finland, Sweden and Norway are timberframed, and this system has now been introduced on a large scale in emerging countries (Russia, Chile, South Korea, China, Taiwan (Inat, 2011). 
Although this system is still relatively new in Mexico, Sánchez (2012) indicates that there have been traditional building systems using wood as the main material, such as the "Casa Absidial" (in Tabasco) and the traditional "Troje" house (in Michoacán); both are characterized by being built informally by adapting to the area's climatic conditions.

Elorza (1984) indicates that the main problem involved in wood construction in those years was the lack of standards, which is why the National Advisory Committee for the Standardization of Public Housing with Wood Elements was established. Subsequently, a number of standards were adopted under the auspices of various institutions; beginning in 1979, more than 4,000 houses and 11,000 unfinished dwellings were built with wood elements (studs, roof structures, among others) in the states of Baja California, Durango, Chihuahua, State of Mexico, Guerrero and Mexico City.

In 1985, the National Popular Housing Fund (FONHAPO) held the first popular housing contest with wood elements and about 2,000 wood frame houses were built in the states of Durango, Chiapas, Guerrero and Michoacán (CT-DCM, 2014).

In 1994, the first edition of the Light Wood Frame Construction Manual (MCELM) (COFAN, 1994) was completed with support and funding from the United States and Canada. Subsequently, in 1999, the manual's second edition (COFAN, 1999) was published.

From 2005 to 2016, the National Council for Wood Construction (COMACO) held nine timber housing competitions in different categories, highlighted by ones related to rural housing, sustainable housing, affordable housing and emergency housing. In the 9th competition in 2014, the organizing committee consisted of: COMACO, the National Forestry Commission (CONAFOR); The Ministry of Agrarian, Territorial and Urban Development (SEDATU); The National Housing Commission (CONAVI); The Housing Fund of the Institute for Social Security and Services for State Workers (FOVISSSTE); FONHAPO; The Federal Mortgage Society (SHF); The National Council of Regional Housing Organizations (CONOREVI) and the College of Architects of Mexico City (CAM-SAM).

Up until 2014, 634 homes were built with wood in the states of Chiapas, Guerrero, Sinaloa and Tamaulipas (CT- DCM, 2014).

The current construction trend in wood frame housing is the building of "prefabricated" houses. Sánchez (2012) defines them as "systems and elements fabricated in a workshop that are later assembled at a construction site with standard measures"; some of these systems are located in Denmark, South Korea and Spain.

Efforts are underway by the Federal Government, private companies and research centers, among others, to promote the use of wood in construction through strategies such as contests to design a wood frame dwelling, the granting of loans to acquire a public housing unit, or simply the promotion of "Sustainable Housing" to help cope with the major problem posed today by climate change.

An unfounded fear concerning the use of wood in building is the belief that the wood will degrade quickly and the building will only last a short time; the only real disadvantage of using wood compared to other materials is the lack of knowledge of its physical and mechanical properties on the part of the vast majority of construction professionals (architects, engineers, contractors, etc.).

The aim of this research was to carry out a wood frame house construction project, by indicating the step-by-step construction sequence, based on Mexican standards applicable to timber, regulations, complementary technical standards and construction manuals; the technical basis for the manuals is rooted in the experience of countries such as the United States, Canada and Chile.

Methodology

The technical support for COFAN's 1999 manual, a core part of the project, was based on Mexico City's Building Regulations and the city's Complementary Technical Standards of 1987 (RCDF and NTCRCDF respectively); however, the information was updated so that the methodology would also be based on the recommendations of the RCDF (2004), NTCRCDF (2004), and current ONNCCE Mexican standards (NMXs), applicable to timber. In addition, information from different manuals related to wood construction was considered: CORMA (2004), JUNAC (1980) Parker and Ambrose (2012), among others.

The MCELM design method is that of limit states; the limit state approach is a format where all aspects of design are considered in an orderly and rational way and that allows easy incorporation of probabilistic criteria (COFAN, 1999). 
It is important to mention that a specific place was not considered for the housing project (despite having used the information from Mexico City's regulations); however, NMXs provide the information necessary to build housing anywhere in the country, taking into account, of course, the regulations and environmental characteristics of the place where it is built.

However, the dwelling's living spaces were taken into account and designed to meet the needs of a family of four: two bedrooms (master bedroom and one for children), living room, dining room, kitchen, laundry room and bathroom with shower (Figure 1).

Figure 1.Distribution of living spaces

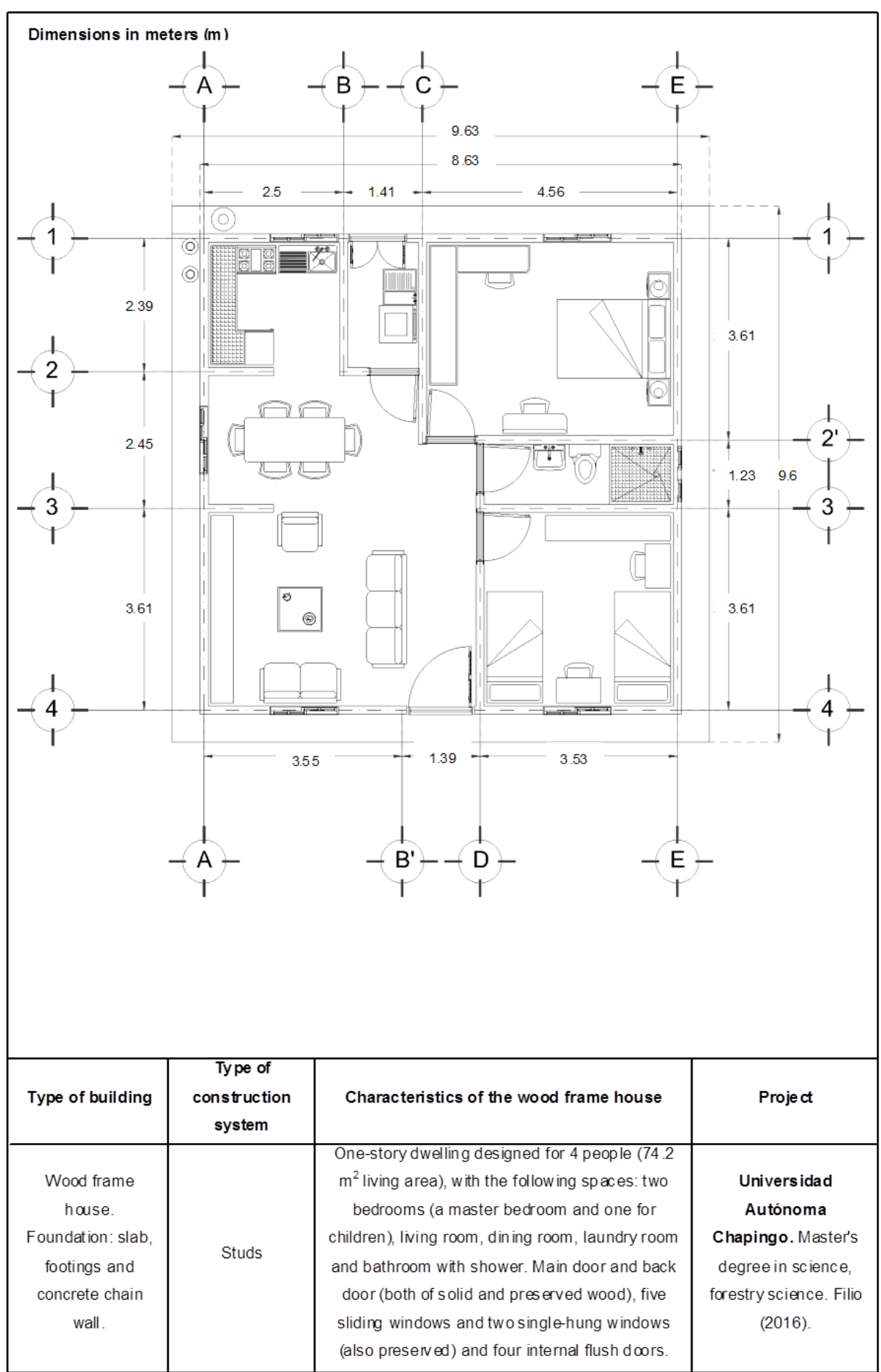

Different models and styles of wood frame houses were reviewed in COMACO technical project reports, construction and structural design manuals, scientific articles, master and bachelor's theses, books, Internet sites and brochures, to determine the model best suited to the characteristics of the living spaces mentioned above. 
Once the type of dwelling (a one-story rural dwelling with a gable roof) was chosen, the living spaces and panels were designed based on the rules established by the wood frame building system (Table 1); i.e. for commercial $4 \times 8$ feet ( 1.22 x $2.44 \mathrm{~m}$ ) plywood sheets, the spacing between the horizontal center point of each stud is $24 "(61 \mathrm{~cm})$.

Table 1. Requirements for light wood frame construction. Source: Parker and Ambrose (2012).

\begin{tabular}{|c|c|c|c|c|}
\hline \multirow[t]{2}{*}{$\begin{array}{c}\text { Stud dimensions } \\
\text { (inches) }\end{array}$} & \multicolumn{2}{|c|}{ Load walls } & \multicolumn{2}{|c|}{ Partition walls } \\
\hline & $\begin{array}{l}\text { Shwb } \\
\text { (feet) }\end{array}$ & $\begin{array}{l}\text { Sorc Separation } \\
\text { (inches) }\end{array}$ & $\begin{array}{l}\text { Sorc } \\
\text { (feet) }\end{array}$ & $\begin{array}{l}\text { Separation } \\
\text { (inches) }\end{array}$ \\
\hline $2 \times 4^{\prime \prime}$ & 10 & 24 & 14 & 24 \\
\hline
\end{tabular}

Shwb = Stud height without bracing.

Sorc $=$ Supports only roof and ceiling.

The sanitary, hydraulic and electric installations were designed on the basis of the distribution of the dwelling spaces in the plans, along with the recommendations indicated in the wood construction manuals, RCDF (2004) and NTCRCDF (2004). The plans, construction sequence and area and volume calculations were done with the AutoCAD 2010 program.

Site selection was carried out according to the recommendations of CORMA (2004), JUNAC (1980) and the Complementary Technical Standards for Foundation Design and Construction (NTCRCDF, 2004). The leveling, layout, excavation and design work for the foundation (Table 2) were carried out according to the recommendations of CORMA (2004), CONAFOR (n.d.) and COFAN (1999).

Table 2.Elements of foundation systems for wood structures. Source: COFAN (1999).

\begin{tabular}{lccc}
\hline Foundation system & Footings & Supports & Ground floor \\
\hline Foundations & Continuous spread & Isolated perimeter & Concrete \\
independent of the & footings and central & load walls and & slab on the \\
concrete slab & dadoes & isolated dadoes & ground \\
\hline
\end{tabular}

Building the house will require a volume of $\pm 9 \mathrm{~m}^{3}$ of pinewood (studs, fascias, struts, support beams, plywood sheets, among others); of that volume, approximately $50 \%$ corresponds to pine plywood sheets, the veneers of which are obtained in the plywood industry during the unwinding process.

For the project, sawn Mexican pine lumber with a normal density $(\mathrm{Nd})$ of $0.54 \mathrm{~g} / \mathrm{cm}^{3}(\mathrm{Nd}=$ weight at $12 \%$ moisture content /volume at $12 \%$ moisture content), equivalent to $543 \mathrm{~kg} / \mathrm{m}^{3}$, was considered. The nominal dimensions of the studs were set at $2 \times 4$ " (actual dimensions were determined according to Table 3 ).

\begin{tabular}{|c|c|c|c|c|c|}
\hline \multicolumn{2}{|c|}{ Thickness (mm) } & \multicolumn{2}{|c|}{ Width $(\mathrm{mm})$} & \multicolumn{2}{|c|}{ Length $(\mathrm{mm})$} \\
\hline $\mathrm{D}$ & $T$ & $\mathrm{D}$ & $T$ & $\mathrm{D}$ & $T$ \\
\hline 38 & \pm 1.0 & 89 & \pm 1.5 & 2440 & \pm 6.0 \\
\hline
\end{tabular}

To classify wood, COFAN (1999) groups Mexican conifer species into ten groups, from CE1 to CE10, in relation to the specified strength and modulus of elasticity values. Groups CE5 and CE7 correspond to Class "B" wood (special rules) and Class "A" wood (industrial rules) in NMX-C-239-ONNCCE (1985); these two strength classes are specified in the Complementary Technical Standards for the Design and Construction of Wood Structures (NTCRCDF, 2004).

Plans for the structure call for the wood to be preserved with CCA salts, by pressure or vacuum methods, in accordance with the recommendations of CORMA (2004), COFAN (1999) and CONAFOR (n.d.), and the specifications of NMX-C-178ONNCCE (2014), NMX-C-322-ONNCCE (2014) (Table 4), NMX-C-410-ONNCCE (1999) and NMX-C-419-ONNCCE (2014). 
Table 4.Recommended minimum retentions of the preservative or active ingredient, according to the level of risk in wood service, $\mathrm{kg} / \mathrm{m}^{3}\left(\mathrm{lb} / \mathrm{foot}^{3}\right)$. Source: NMX-C-322-ONNCCE (2014).

\begin{tabular}{lcccccc}
\hline & & \multicolumn{5}{c}{ Level of risk } \\
\cline { 3 - 7 } Type & Preservative & R1 & R2 & R3 & R4 & R5 \\
\hline Water- & CCA & 4.00 & 6.40 & 9.60 & 12.8 & 40.0 \\
soluble & & $(0.25)$ & $(0.40)$ & $(0.60)$ & $(0.80)$ & $(2.50)$ \\
\hline
\end{tabular}

Openings (doors and windows) were designed according to the recommendations of Hanono (2005) and CORMA (2004) and the percentage that they must comply with to avoid or decrease the use of heaters (in cold weather places) and air conditioning (in hot weather places) as indicated by NMX-C-460-ONNCCE (2009).

For the design of the panels, the recommendations of CORMA (2004), COFAN (1999), CONAFOR (n.d.) and Hanono (2005) were taken into account; the nailing was established in accordance with the UBC (Uniform Building Code). In order to join the continuous panels using "L" and "T" joints, corner posts were designed with $32 \times 89 \times 305 \mathrm{~mm}$ spacing (Figure 2).

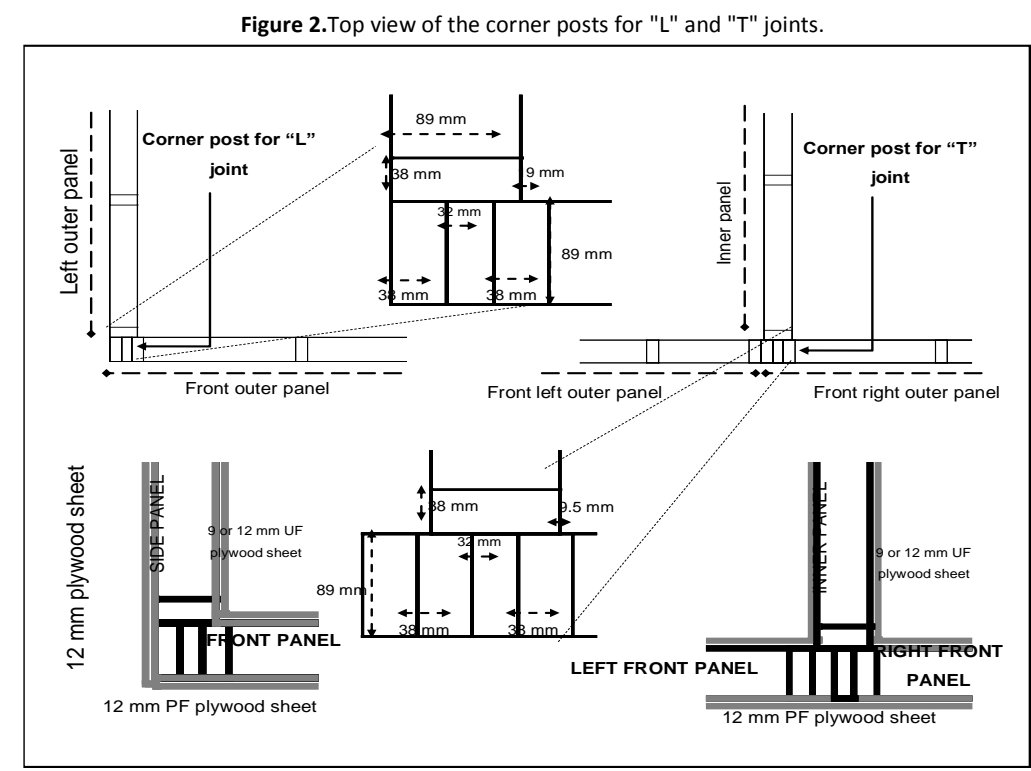

Roof dead loads were calculated (Table 5); subsequently with these data, the covering (roof) was classified as indicated (Table 6); the classification of the wood with NMX-C-239-ONNCCE (1985) allowed determining the maximum framework spacing (Table 7) and verifying the correct spacing between 24 " studs (Table 8), both according to group CE7.

\begin{tabular}{lcccccc}
\multicolumn{8}{c}{ Table 5.Dead loads $\left(\mathrm{kg} / \mathrm{m}^{2}\right)$ of the materials proposed for the house roof. } \\
\hline $\begin{array}{l}\text { Wood at } \\
18 \% \mathrm{MC}\end{array}$ & $\begin{array}{c}\text { (plywood or } \\
\text { OSB) }\end{array}$ & $\begin{array}{c}12 \mathrm{~mm} \text { Gypsum } \\
\text { boards } \\
\text { (indoors) }\end{array}$ & $\begin{array}{c}\text { Asphalt } \\
\text { shingles }\end{array}$ & $\begin{array}{c}\text { Asphalt } \\
\text { Felt }\end{array}$ & $\begin{array}{c}\text { Total dead } \\
\text { load }\end{array}$ & Others \\
\hline 9.09 & 8.49 & 4.5 & 9.11 & 0.7 & 32.37 & $\leq 7.63$ \\
\hline Others = nails, screws, metal drip edges, among others.
\end{tabular}

\begin{tabular}{|c|c|c|c|}
\hline System & $\begin{array}{c}\text { Maximum } \\
\text { live load }{ }^{1} W_{m}\end{array}$ & $\begin{array}{c}\text { Dead } \\
\text { load } W_{p}\end{array}$ & $\begin{array}{c}\text { Total load } 1.4 \\
\left(W_{m}+W_{p}\right)\end{array}$ \\
\hline \multicolumn{4}{|l|}{ Floors } \\
\hline Dwelling & 170 & 50 & 308 \\
\hline Office & 250 & 60 & 434 \\
\hline \multicolumn{4}{|l|}{ Coverings } \\
\hline Flat light (slope $<5 \%$ ) & 100 & 40 & 196 \\
\hline Inclined light (slope > 5\%) & 40 & 40 & 112 \\
\hline Flat heavy (slope < 5\%) & 100 & 110 & 294 \\
\hline Inclined heavy (slope > 5\%) & 40 & 110 & 210 \\
\hline
\end{tabular}

${ }^{1}$ Art. 199, RCDF-87.

$\mathrm{L}_{\mathrm{f}}=$ Load factor (1.4). 
Table 7. Maximum clearances of gable roof trusses (L). Lightweight coverings. Live load: $W_{v}=40 \mathrm{~kg} / \mathrm{m}^{2}$; Dead load: $W_{P}=60 \mathrm{~kg} / \mathrm{m}^{2}, \mathrm{spacing} S=61 \mathrm{~cm}$. Source: COFAN (1999).

\begin{tabular}{|c|c|c|c|c|c|c|c|c|c|c|c|c|}
\hline \multirow{2}{*}{$\begin{array}{c}\text { Upper } \\
\text { chord } \\
\text { section } \\
(\mathrm{mm})\end{array}$} & \multirow{2}{*}{$\begin{array}{c}\text { Lower } \\
\text { chord } \\
\text { section } \\
(\mathrm{mm})\end{array}$} & \multirow[b]{2}{*}{$\begin{array}{l}\text { Roof } \\
\text { slope }\end{array}$} & \multicolumn{10}{|c|}{ Structural group } \\
\hline & & & CE1 & CE2 & CE3 & CE4 & CE5 & CE6 & CE7 & CE8 & CE9 & CE10 \\
\hline \multirow{4}{*}{$38 \times 89$} & $38 \times 89$ & $1 / 4.8$ & - & & 5.80 & 7.24 & 8.03 & 8.62 & 9.20 & 9.79 & 10.38 & 10.96 \\
\hline & & $1 / 4$ & - & 4.40 & 6.67 & 7.84 & 8.73 & 9.12 & 9.70 & 10.28 & 10.87 & 11.11 \\
\hline & & $1 / 3$ & - & 5.88 & 7.59 & 8.61 & 9.41 & 9.87 & 10.44 & 11.11 & 11.11 & 11.11 \\
\hline & & $1 / 2.4$ & 4.40 & 6.57 & 8.12 & 9.16 & 9.90 & 10.34 & 10.89 & 11.11 & 11.11 & 11.11 \\
\hline
\end{tabular}

Table 8. Bearing loads per linear meter of wall based on frames $(\mathrm{kg} / \mathrm{m} . \mathrm{l} .)^{1}$. Source: COFAN (1999).

\begin{tabular}{|c|c|c|c|c|c|c|c|c|c|}
\hline \multirow{2}{*}{$\begin{array}{l}\text { Section } \\
(\mathrm{mm})\end{array}$} & \multirow{2}{*}{$\begin{array}{c}\mathrm{S} \\
(\mathrm{cm})\end{array}$} & \multirow{2}{*}{$\begin{array}{l}\text { Height } \\
\text { (m) }\end{array}$} & \multicolumn{7}{|c|}{ Structural group } \\
\hline & & & CE1 & CE2 & CE3 & CE4 & CE5 & CE6 & CE7 \\
\hline $38 \times 89$ & 61 & 2.44 & 412 & 645 & 913 & 1217 & 1527 & 1736 & 2045 \\
\hline
\end{tabular}

${ }^{1}$ The design conditions are: dry condition and normal load duration. $S=$ Spacing.

The eaves design (Figure 3) was made according to Elizondo (2009), and the fascia design according to JUNAC (1980). In the design of the envelope (walls and roof), Mexican-made pinewood plywood sheets manufactured with phenol formaldehyde (PF) were considered, according to the specifications of NMX-C-411-ONNCCE (1999), NMX-C-438ONNCCE (2014), NMX-C-439-ONNCCE (2006) and NMX-C-440-ONNCCE (2006). Imported plywood sheets may be used provided they meet the specifications indicated in the project, or Oriented Strand Boards (OSB).

For the application of surface finishes and coatings, the recommendations of JUNAC (1988), CONAFOR (n.d.) and COFAN (1999) were taken into account

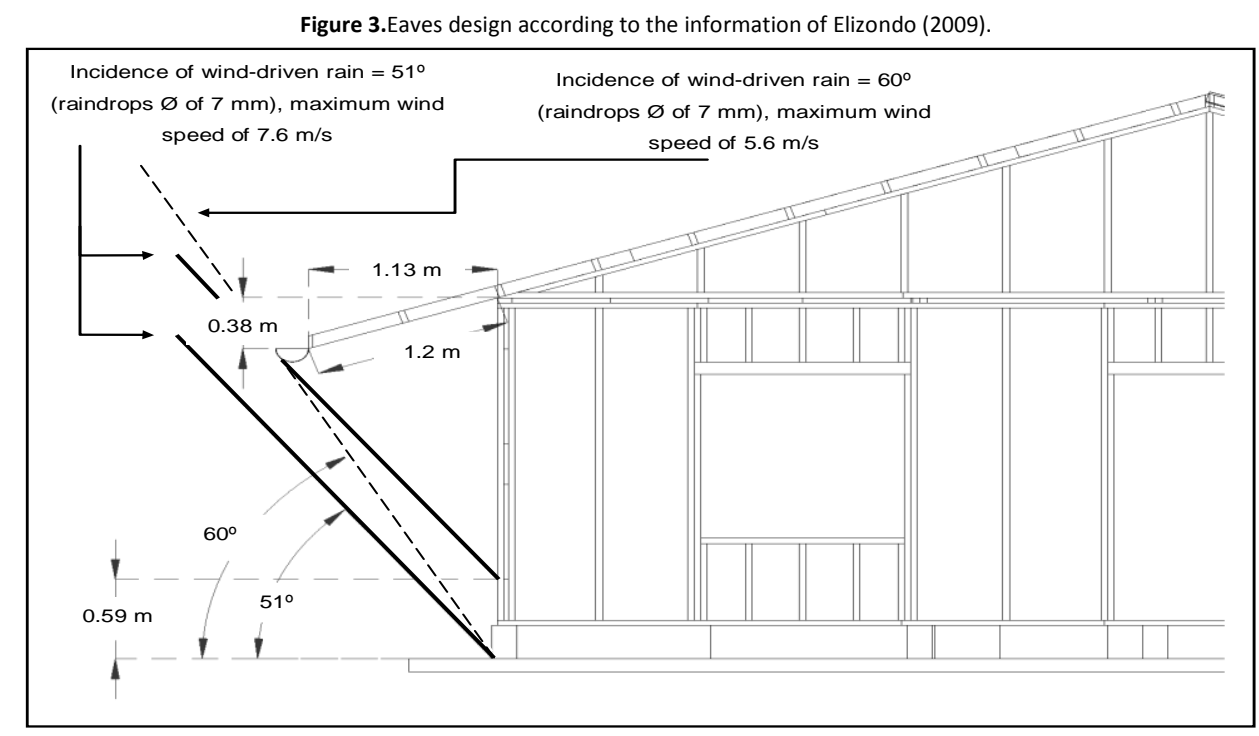

Results

A design was made to construct a rural, one-story pinewood home for four people, with a gable roof, a mortar surface finish and asphalt shingle covering (Figure 4). The dimensions were: roof covering area $106.43 \mathrm{~m}^{2}$, foundation slab area $92.44 \mathrm{~m}^{2}$, living area $74.2 \mathrm{~m}^{2}$, and a height of $4.33 \mathrm{~m}$ from the finished floor level (FFL) (Figure 5). 

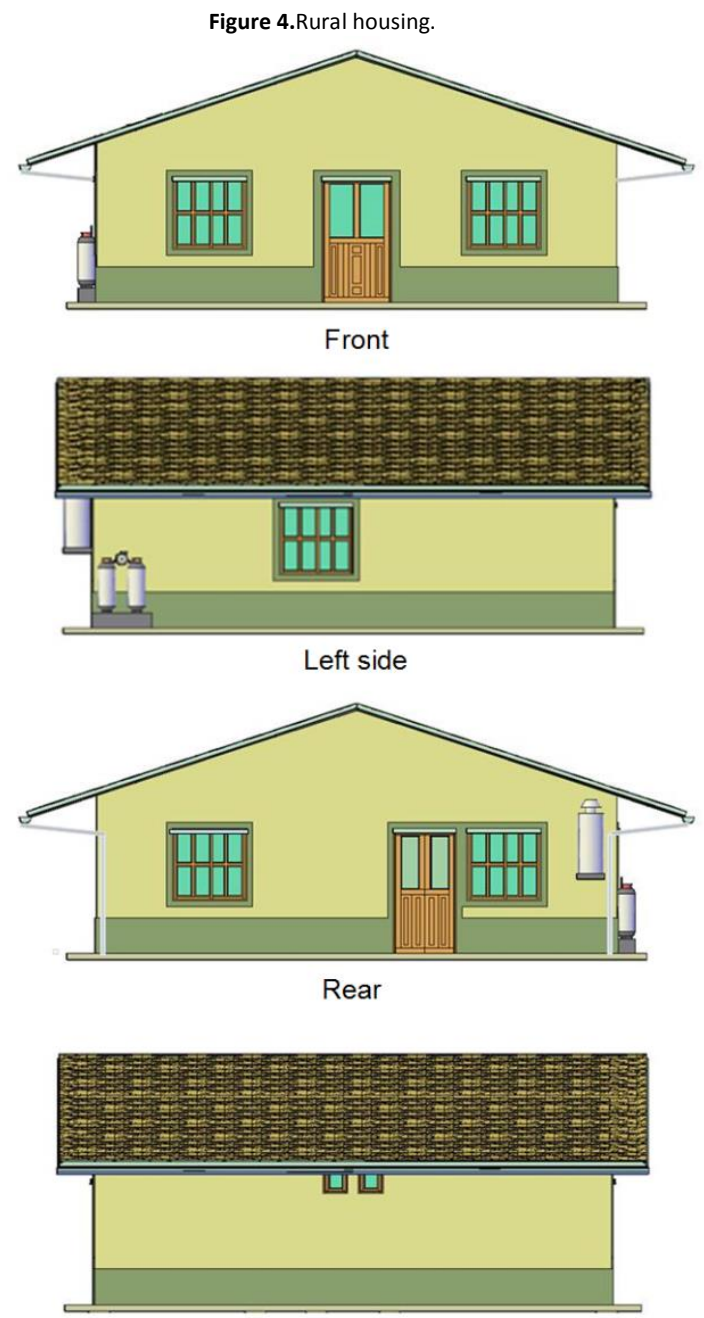

Right side

For site selection, a plot with good drainage located away from rivers, bodies of water or high-moisture areas was considered. The orientation of the house in relation to weather and solar radiation depends on the place where it is built.

Figure 6 shows the foundation profile, materials, characteristics and dimensions. Footings structured with $4,10 \mathrm{~mm}$ $\left(3 / 8^{\prime \prime}\right)$ diameter rods and $6 \mathrm{~mm}\left(1 / 4^{\prime \prime}\right)$ diameter stirrups every $20 \mathrm{~cm}$, with a load factor $(\mathrm{LF})=200 \mathrm{~kg} / \mathrm{cm}^{2}$, were designed. 
Figure 5. Roof dimensions.

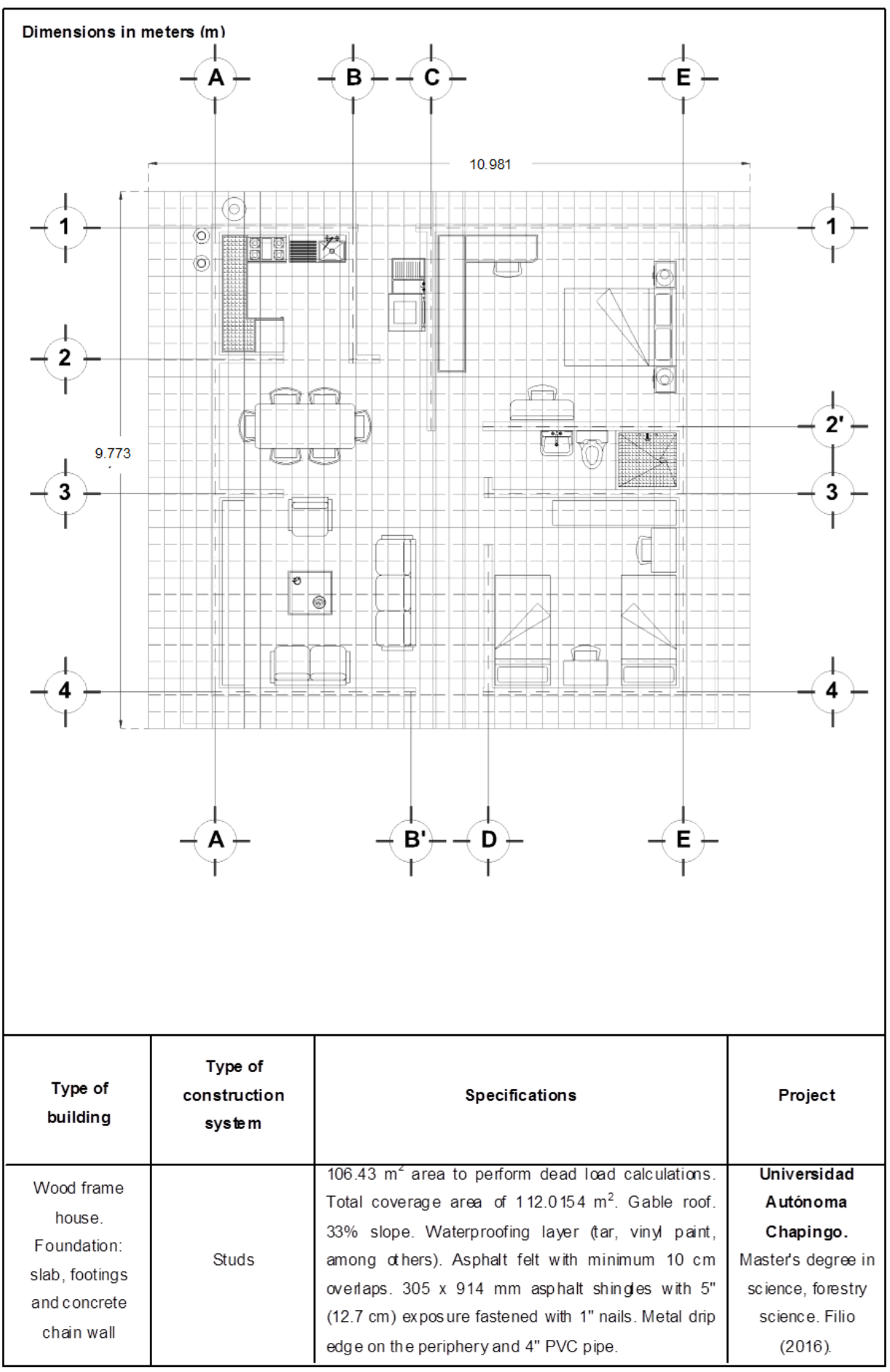

Figure 6.Profile of the placement of the materials in the foundation.

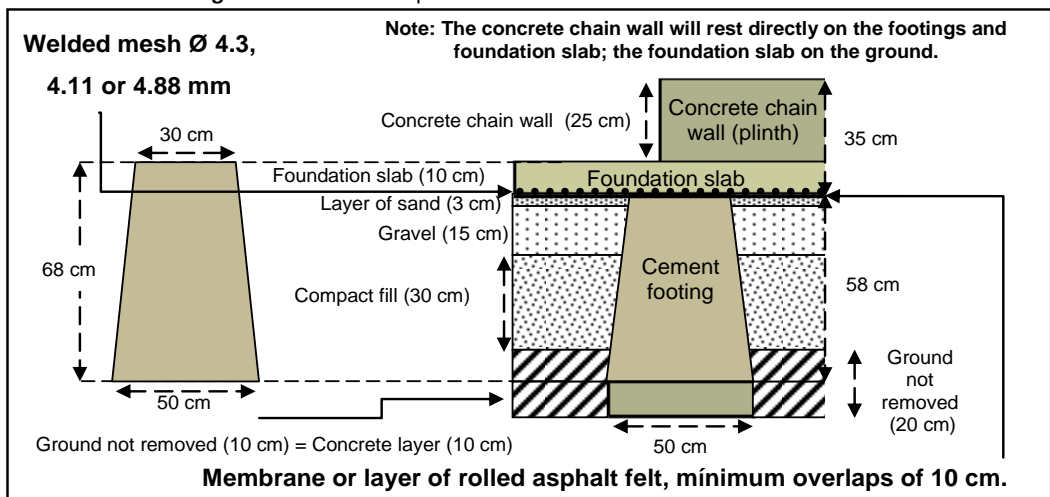


Prior to pouring the slab $\left(\mathrm{LF}=200 \mathrm{~kg} / \mathrm{cm}^{2}\right)$, galvanized steel anchor bolts of $10 \mathrm{~mm}\left({ }^{3} / \mathrm{s}^{\prime \prime}\right)$ or $13 \mathrm{~mm}\left({ }^{1} / 2^{\prime \prime}\right)$ in diameter and $30 \mathrm{~cm}$ in length (with nut and washer)will be placed to secure the welded mesh to the concrete chain wall. The framework designed for the concrete chain wall $\left(\mathrm{LF}=150 \mathrm{~kg} / \mathrm{cm}^{2}\right)$ includes 4 rods of $12 \mathrm{~mm}\left({ }^{1} / 2^{\prime \prime}\right)$ or $16 \mathrm{~mm}\left({ }^{5} / \mathrm{s}^{\prime \prime}\right)$ in

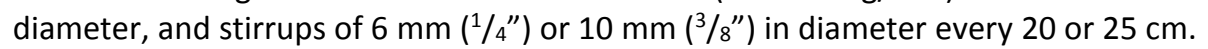

To hold the panels in place against the forces of wind and earthquake, galvanized bolts of $13 \mathrm{~mm}\left(1 / 2^{\prime \prime}\right)$ in diameter and $30 \mathrm{~cm}$ in length, embedded $20 \mathrm{~cm}$ in the concrete chain wall, will be placed (Figure 7).

Figure 7.Foundation.

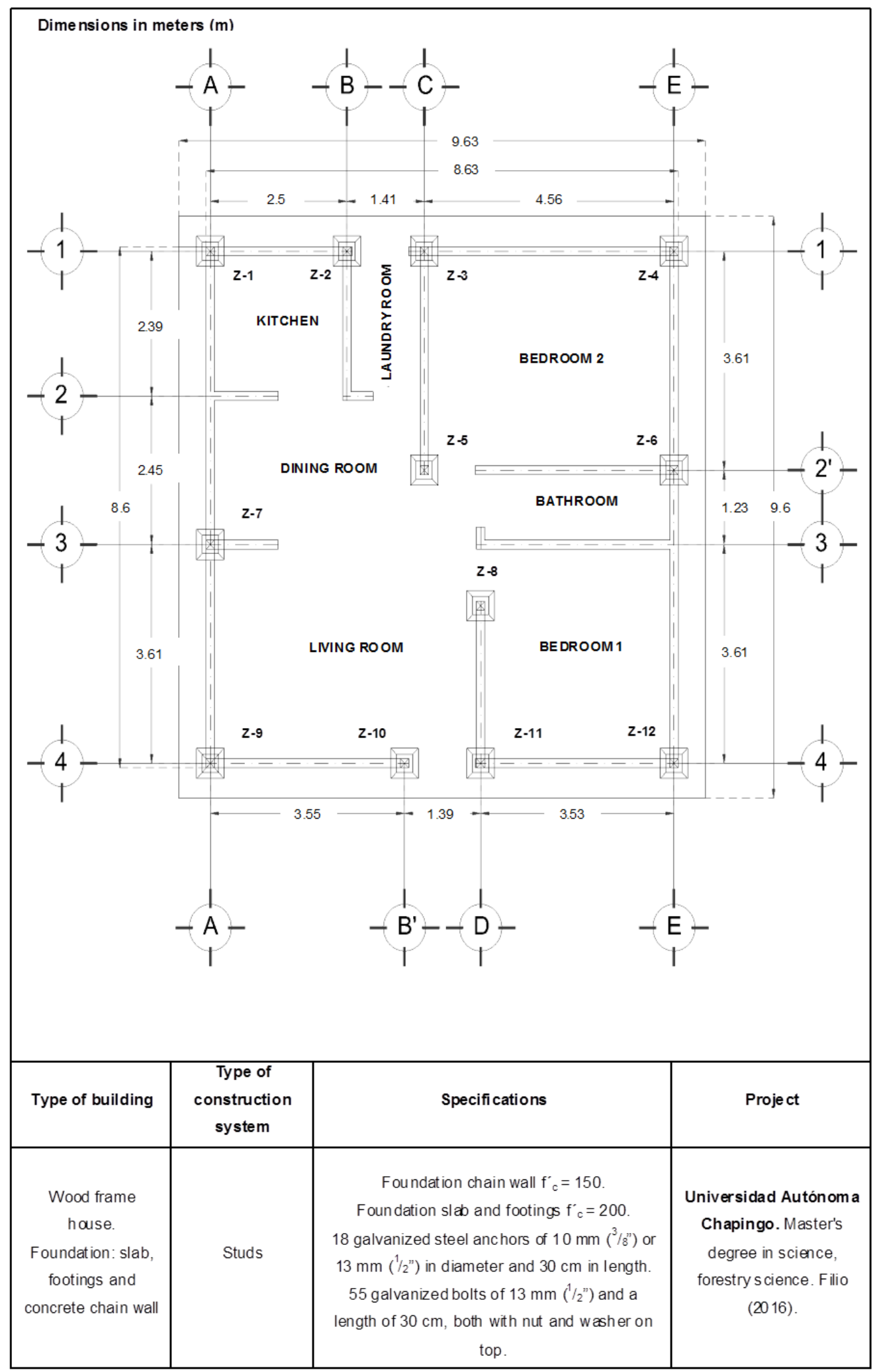


The structure was designed with nominal 2 × 4" studs ( $38 \times 89 \mathrm{~mm}$ actual, $\mathrm{MC}+/-12 \%$ ), with a $\mathrm{Nd}=0.54 \mathrm{~g} / \mathrm{cm}^{3}, \mathrm{preferably}$ from radial cuts (more dimensionally stable); they were classified with the industrial rule (Class "A", group CE7), preserved with CCA salts at recommended minimum retentions of $4.00,6.40$ and $9.60 \mathrm{~kg} / \mathrm{m}^{3}$ according to their location in the dwelling.

The following openings were designed: front and back doors (solid wood); four interior (flush) doors; five sliding windows (four as a means of escape at a height of $1 \mathrm{~m}$ from the $\mathrm{FFL}$ ) and two single-hung windows in the bathroom. $A$ percentage of $14 \%<20 \%$ indicated in NMX-C-460-ONNCCE (2009) was obtained.

The panels were designed to a height of $2.44 \mathrm{~m}(8 \mathrm{ft})$. Three supports were used for each window (width of $1.22 \mathrm{~m})$. The lintels were designed with $38 \mathrm{~mm}$ pieces and the jambs run to the support formwork.

A fiberglass or asphalt felt covering ( 1.3 to $2.5 \mathrm{~cm}$ ) was considered as a sealant and moisture protectant for the support formwork; the panels will be fastened to the bolts with nuts and washers. At the junction between panels, the upper sill and enclosure were designed so that they would be offset by at least the separation of 1 stud (24").

A 33\% slope was determined for the roof; the eaves were designed according to a maximum wind speed of $5.6 \mathrm{~m} / \mathrm{s}$ with a raindrop diameter of $7 \mathrm{~mm}$, for an angle of $60^{\circ}$, according to Elizondo (2009).

The Fink truss was correctly designed with a clearance of $8.56 \mathrm{~m}$, according to Table 7 ( $<10.44 \mathrm{~m})$. A roof dead load of $32.37 \mathrm{~kg} / \mathrm{m}^{2}$ was calculated and, when considering the "other" dead loads, $\approx 40 \mathrm{~kg} / \mathrm{m}^{2}$ was obtained (Table 5). The roof was considered as a light covering (Table 6) with a total load of $112 \mathrm{~kg} / \mathrm{m}^{2}$ (dead load of $40 \mathrm{~kg} / \mathrm{m}^{2}+\mathrm{live} \mathrm{load} \mathrm{of} 40 \mathrm{~kg} / \mathrm{m}^{2}$, both multiplied by a load factor of 1.4).

In placing the trusses, a separation of $61 \mathrm{~cm}$ between centers, fastened with $1 \times 4$ " struts (diagonal and longitudinal), was considered. Pieces larger than 8 feet are recommended on the sloping sills of the trusses to provide greater stability to the structure; the pieces will be secured with $12 \mathrm{~mm}$ plywood gussets of urea formaldehyde (UF) resin.

Calculations were made to check the bearing loads of the studs according to the 61-cm spacing indicated in Table 8, obtaining for a $6-\mathrm{m}$ tributary width a frame bearing load result of $713 \mathrm{~kg} / \mathrm{m}$. According to Table 8 , the bearing load per linear meter is more than adequate for Class "A" (CE7), and even Class "B" (CE5) can be used without any problem.

The outer walls were designed to vertically place12 $\mathrm{mm}$ plywood sheets of moisture-resistant phenol formaldehyde resins (PF) with a clearance of $3 \mathrm{~mm}$ regardless of the quality of their surface since mortar will be used, fastened with $2^{1} / 2^{\prime \prime}$ nails every $15 \mathrm{~cm}$ at the edges and $30 \mathrm{~cm}$ at the center.

Plans call for the inner walls to be comprised of vertically-placed 9 or $12 \mathrm{~mm}$ UF plywood sheets (quality A or B) with a clearance of $3 \mathrm{~mm}$, secured with $2^{1} / 2^{\prime \prime}$ nails for $12 \mathrm{~mm}$ sheets and 2" nails for $9 \mathrm{~mm}$ ones, every $15 \mathrm{~cm}$ at the edges and $30 \mathrm{~cm}$ at the center.

For the roof, the boards are to be nailed onto the upper chords of the trusses in a perpendicular direction, leaving a 3 $\mathrm{mm}$ space between the edges to avoid damage due to volumetric changes. They should be interspersed, nailed with 2 or $2^{1 / 2 "}$ nails, spaced $15 \mathrm{~cm}$ at the edges and $30 \mathrm{~cm}$ at the center. When it is necessary to provide for diaphragm-like motion or high-speed winds, $2,2^{1} / 2$ or $3^{\prime \prime}$ nails with 7 to $15 \mathrm{~cm}$ spacing will be used, both on the edges and on the inner supports.

Surface materials and finishes, such as waterproofing, asphalt felt, mortar and paints, must always be considered as they ensure the proper protection of a wood frame house.

The type and placement of thermal and acoustic insulation materials, among others, will depend to a large extent on the location of the home and the builder's budget. In the case of gypsum sheets (indoors), they must be fire resistant and some should be moisture resistant, as in the case of the bathroom and laundry room, both $12 \mathrm{~mm}$.

Discussion

According to the CT-DCM (2014), COMACO-organized wood frame housing contests, supported by several institutions, have placed special emphasis on the promotion of rural housing, sustainable housing and affordable housing. The house must comply with a number of requirements, such as a maximum construction cost and a higher percentage of wood compared to other building materials, and it must also be sustainable in nature. 
In order to design and subsequently build a wood frame house, there are different styles of housing ranging from the cheapest ones, such as a rural dwelling (Ángeles, 2010), to residential houses (Barajas, 2009); despite that, the quality of the wood should be the same regardless of the style of the house.

"Affordable housing" can be considered as ranging fromMXN\$36,000.00 (USD\$1,895.00), as indicated by Ángeles (2010), to MXN\$60,000.00 (USD\$3,158.00) according to COFAN (1999); the cost of "middle-level housing" is about MXN\$105,000.00 (USD\$5,526.00) according to FITECMA (2011), whereas "residential-type housing" goes up to MXN\$1,450,000.00 (USD\$76,316.00) according to Barajas (2009). The exchange rate at which the calculation was made was $\$ 1.00$ USD $=\$ 19.00 \mathrm{MXN}$. The unit and total costs of constructing this type of house are presented in Table 9.

\begin{tabular}{|c|c|c|c|c|c|c|c|}
\hline Category & Description & Material & Quantity & $\begin{array}{l}\text { Approx. Unitary } \\
\text { price (MXN) }\end{array}$ & $\begin{array}{l}\text { Import price } \\
\quad(\mathrm{MXN})\end{array}$ & $\begin{array}{c}\text { Unit } \\
\text { price } \\
\text { in } \\
\text { dollars }\end{array}$ & $\begin{array}{l}\text { Import } \\
\text { price in } \\
\text { dollars }\end{array}$ \\
\hline \multirow{3}{*}{$\begin{array}{l}\text { Preliminary } \\
\text { activities }\end{array}$} & Clearing & & & 5.00 & 462.00 & 0.26 & 24.32 \\
\hline & Layout and Levelling & & $9.6 \mathrm{~m} \times 9.63 \mathrm{~m}$ & 4.00 & 369.79 & 0.21 & 19.46 \\
\hline & $\begin{array}{l}\text { Excavation and } \\
\text { compactation }\end{array}$ & $\begin{array}{l}\text { Includes tools and } \\
\text { labor }\end{array}$ & 44 cubic meter & 100.00 & 4400.00 & 5.26 & 231.58 \\
\hline \multirow[t]{18}{*}{ Foundation } & Slab base & Sand & 2.77 cubic meter & 144.00 & 398.80 & 7.58 & 20.99 \\
\hline & & Gravel & 13.85 cubic meter & 150.00 & 2077.50 & 7.89 & 109.34 \\
\hline & Concrete bases & Cement & 12 bases ( 6 bags) & 167.00 & 1002.00 & 8.79 & 52.74 \\
\hline & Footings & Cement & 12 footings ( 25 bags) & 167.00 & 4175.00 & 8.79 & 219.74 \\
\hline & & Rods $3 / 8 "$ & 4 rods of $12 \mathrm{~m}$ & 75.00 & 300.00 & 3.95 & 15.79 \\
\hline & & Rings $1 / 4 "$ & 9 rolls of $4 \mathrm{~m}$ & 16.00 & 144.00 & 0.84 & 7.58 \\
\hline & Asphalt felt & Spool & 5 spools of 26 square meter & 285.00 & 1425.00 & 15.00 & 75.00 \\
\hline & Slab & Cement & 35 bags & 167.00 & 5845.00 & 8.79 & 307.63 \\
\hline & & Sand & 2.82 cubic meter & 144.00 & 406.08 & 7.58 & 21.37 \\
\hline & & Gravel & 4.58 cubic meter & 150.00 & 687.00 & 7.89 & 36.16 \\
\hline & & Welding mesh 6" x 6" & Rolls of $2.5 \mathrm{~m} \times 40 \mathrm{~m}$ & 3335.00 & 3335.00 & 175.53 & 175.53 \\
\hline & Chain wall & Cement & 7 bags & 157.00 & 1169.00 & 8.26 & 61.53 \\
\hline & & Sand & 0.70 cubic meter & 144.00 & 100.80 & 7.58 & 5.31 \\
\hline & & Gravel & 0.81 cubic meter & 150.00 & 121.50 & 7.89 & 6.39 \\
\hline & & Rods 5/8" & 17 rods of $12 \mathrm{~m}$ & 90.00 & 1530.00 & 4.74 & 80.53 \\
\hline & & Rings $1 / 4 "$ & 64 rolls of $4 \mathrm{~m}$ & 16.00 & 1024.00 & 0.84 & 53.89 \\
\hline & $\begin{array}{l}\text { Metal fasteners (stainless } \\
\text { steel) }\end{array}$ & $\begin{array}{c}\text { Anchors 1/2" } \\
\text { Bolts 1/2" }\end{array}$ & 6 rods of $3.6 \mathrm{~m}$ & 640.00 & 3840.00 & 33.68 & 202.11 \\
\hline & Foundation work & & Includes tools & & 18000.00 & 0.00 & 947.37 \\
\hline \multirow[t]{3}{*}{ Installations } & Bathroom: includes bathr & om fixtures, pipes, heate & pipe connection to existing netwo & , tikle and labor & 8500.00 & 0.00 & 447.37 \\
\hline & Hydr & ulics: pipes, valves, pumf & Nater, washing place and labor & & 7300.00 & 0.00 & 384.21 \\
\hline & Electrica & includes switchboard, du & npers, electrical material and labor & & 5000.00 & 0.00 & 263.16 \\
\hline \multirow[t]{16}{*}{ House } & $\begin{array}{l}\text { Lower structure (panels } \\
\text { and tympanums) }\end{array}$ & $\begin{array}{l}\text { Wood preserved with } \\
\text { CCA salt }\end{array}$ & $\begin{array}{c}210 \text { studs of } 38 \mathrm{~mm} \mathrm{x} 89 \mathrm{~mm} \times \\
2440 \mathrm{~mm}\end{array}$ & 150.00 & 31500.00 & 7.89 & 1657.89 \\
\hline & & & $\begin{array}{l}9 \text { studs (15 struts of } 19 \mathrm{~mm} \times 89 \\
\mathrm{~mm} \times 2820 \mathrm{~mm} \text { ) }\end{array}$ & 150.00 & 1350.00 & 7.89 & 71.05 \\
\hline & Siding & & $\begin{array}{l}25 \text { studs of } 38 \mathrm{~mm} \times 89 \mathrm{~mm} \times \\
2440 \mathrm{~mm}\end{array}$ & 150.00 & 3750.00 & 7.89 & 197.37 \\
\hline & $\begin{array}{l}\text { Upper structure (truss, } \\
\text { braces, among others) }\end{array}$ & & $\begin{array}{l}202 \text { studs of } 38 \mathrm{~mm} \mathrm{x} 89 \mathrm{~mm} \times \\
2440 \mathrm{~mm}\end{array}$ & 150.00 & 30300.00 & 7.89 & 1594.74 \\
\hline & & & $\begin{array}{l}78 \text { studs of ( } 6 \text { struts of } 19 \mathrm{~mm} \mathrm{x} \\
89 \mathrm{~mm} \times 7450 \mathrm{~mm})\end{array}$ & 150.00 & 11700.00 & 7.89 & 615.79 \\
\hline & & & $\begin{array}{c}24 \text { studs of } 24 \mathrm{~mm} \times 89 \mathrm{~mm} \times \\
2440 \mathrm{~mm}\end{array}$ & 119.00 & 2846.00 & 6.26 & 149.79 \\
\hline & Doors and windows & & $\begin{array}{l}58 \text { studs of } 38 \mathrm{~mm} \times 89 \mathrm{~mm} \times \\
2440 \mathrm{~mm}\end{array}$ & 150.00 & 8700.00 & 7.89 & 457.89 \\
\hline & Plywood sheets & $\mathrm{PF}(1.22 \mathrm{~m} \times 2.44 \mathrm{~m})$ & 73 & 400.00 & 29200.00 & 21.05 & 1536.84 \\
\hline & & UF (1.22 m x $2.44 \mathrm{~m})$ & 53 & 380.00 & 20140.00 & 20.00 & 1060.00 \\
\hline & Gypsum sheets & Fire $(1.22 \mathrm{~m} \times 2.44 \mathrm{~m})$ & 19 & 120.00 & 2280.00 & 6.32 & 120.00 \\
\hline & & $\begin{array}{c}\text { Moisture }(1.22 \mathrm{~m} \mathrm{x} \\
2.44 \mathrm{~m})\end{array}$ & 6 & 120.00 & 720.00 & 6.32 & 37.89 \\
\hline & Asphalt felt & Envelope & 4 spools of 26 square meter & 285.00 & 1140.00 & 15.00 & 60.00 \\
\hline & & Roof & 5 spools of 26 square meter & 285.00 & 1425.00 & 15.00 & 75.00 \\
\hline & Welded & nesh & Roll of $2.5 \mathrm{~m} \times 40 \mathrm{~m}$ & 3335.00 & 3335.00 & 175.53 & 175.53 \\
\hline & Asphalt shingles & 32 packages & 32 packages & 605.00 & 19360.00 & 31.84 & 1018.95 \\
\hline & \multicolumn{4}{|c|}{ Labor, structure assembly, includes tools and nails } & 28000.00 & 0.00 & 1473.68 \\
\hline Acoustic insulation & Fiberboar & $3 \mathrm{~mm}$ & 60 & 100.00 & 6000.00 & 5.26 & 315.79 \\
\hline \multirow[t]{5}{*}{ Levelling } & Mortar & Cement & 12 bags & 167.00 & 2004.00 & 8.79 & 105.47 \\
\hline & & Sand & 1.2 cubic meter & 144.00 & 172.80 & 7.58 & 9.09 \\
\hline & Labor & & Includes tools & & 7500.00 & & 394.74 \\
\hline & & Total project cost & & & 283035.3 & & 14896.59 \\
\hline & Approximate & onstruction project time & & & 4 weeks & & \\
\hline
\end{tabular}


Sánchez (2012) indicates that engineering work in construction is currently focused on sustainable buildings; this means that its construction processes, residues and drainage collectors must be environmentally friendly and must also take full advantage of the environmental conditions of the place where the building is located.

The reason the wood frame building system was chosen coincides with the view expressed by COFAN (1999); that is, it can be designed for any style of housing, Moreover, it is a system easily adaptable to environmental conditions and, therefore, can be built in any state of Mexico.

The CT-DCM (2014) points out that although the information contained in wood standards is accurate, and based on scientific research carried out by different recognized research centers in Mexico (Universidad Autónoma Chapingo, INIFAP, INECOL, among others), unfortunately builders do not sufficiently examine these standards in detail, and because of this serious errors have been made during the design and construction of wood frame houses.

Flores (2005) mentions that, on average, the sawmilling coefficient (SC) in Mexico is just 50\%, meaning that only half of the wood entering the industry is being used. In this regard, Zamudio (1986) indicates that the utilization coefficient for manufacturing plywood sheets is considered to behalf or even less the transformation coefficient of the wood entering the industry.

Finally, to build a house of this type (Figures 8 to 9), $9 \mathrm{~m}^{3}$ of wood is needed; of this amount, $4.5 \mathrm{~m}^{3}$ of lumber are required to make the studs, fascias, struts, support beams and other structural components. Of this volume, equivalent to $1.9 \mathrm{mbf}$ (thousand board feet), $2 \mathrm{~m}^{3}$ ( $847 \mathrm{bf}$ ) are used to build the walls, and $1.87 \mathrm{~m}^{3}$ (792 bf) to build the roof (framework and struts). The remaining lumber volume, $0.63 \mathrm{~m}^{3}$ ( $267 \mathrm{bf}$ ), is used for doors and windows.

In terms of wood in the form of plywood sheets, the required volume is also equivalent to $4.5 \mathrm{~m}^{3}$ in the form of sheets $12 \mathrm{~mm}$ thick, $1.22 \mathrm{~m}$ wide and $2.44 \mathrm{~m}$ long, which will form the envelope of both the walls and roof.

Under the above assumption, if a small sawmill has an average daily production of $10 \mathrm{mpt}\left(23.6 \mathrm{~m}^{3}\right.$ at a $\left.50 \% \mathrm{SC}\right)$, and its technology allows obtaining studs from radial cuts (more dimensionally stable, according to Espinosa et al. (2010)) based on the correct use of the cutting diagrams, this indicates that one day's production will provide enough lumber to build the structure of 5 houses; however, the actual volume of wood required to build the structure of 5 houses will be 47.2 $\mathrm{m}^{3}$ due to the $50 \% \mathrm{SC}$.

The same can be inferred for the production of plywood sheets, where the utilization coefficient is $50 \%$ or less. It was estimated that approximately $4.5 \mathrm{~m}^{3}$ of pine plywood sheets ( 2.39 and $2.10 \mathrm{~m}^{3}$ of UF and PF sheets, respectively) for a house; this indicates that, similarly to the previous paragraph for the example of $5 \mathrm{dwellings,} 47.2 \mathrm{~m}^{3}$ of wood will be needed to produce the necessary sheets for the housing envelope ( $23.6 \mathrm{~m}^{3}$ of final wood volume).

In fact, it is necessary to consider a volume of $90 \mathrm{~m}^{3}$ of wood (sawn and plywood sheets) to build 5 houses at a $50 \%$ SC in both cases $\left(90 \mathrm{~m}^{3} / 5\right.$ dwellings $=18 \mathrm{~m}^{3} /$ dwelling; $\left.18 * 0.5=9 \mathrm{~m}^{3} / \mathrm{dwelling}\right)$.

Assuming a constant demand for timber by the construction sector, in a working day, depending on the sawmill's capacity and the technology of the cutting diagrams, it is possible to produce the raw material needed to build 5 houses in small sawmills, up to 13 houses in medium-size sawmills and more than 13 houses in large sawmills, with the sawmill characteristics indicated by Sánchez (2008). 

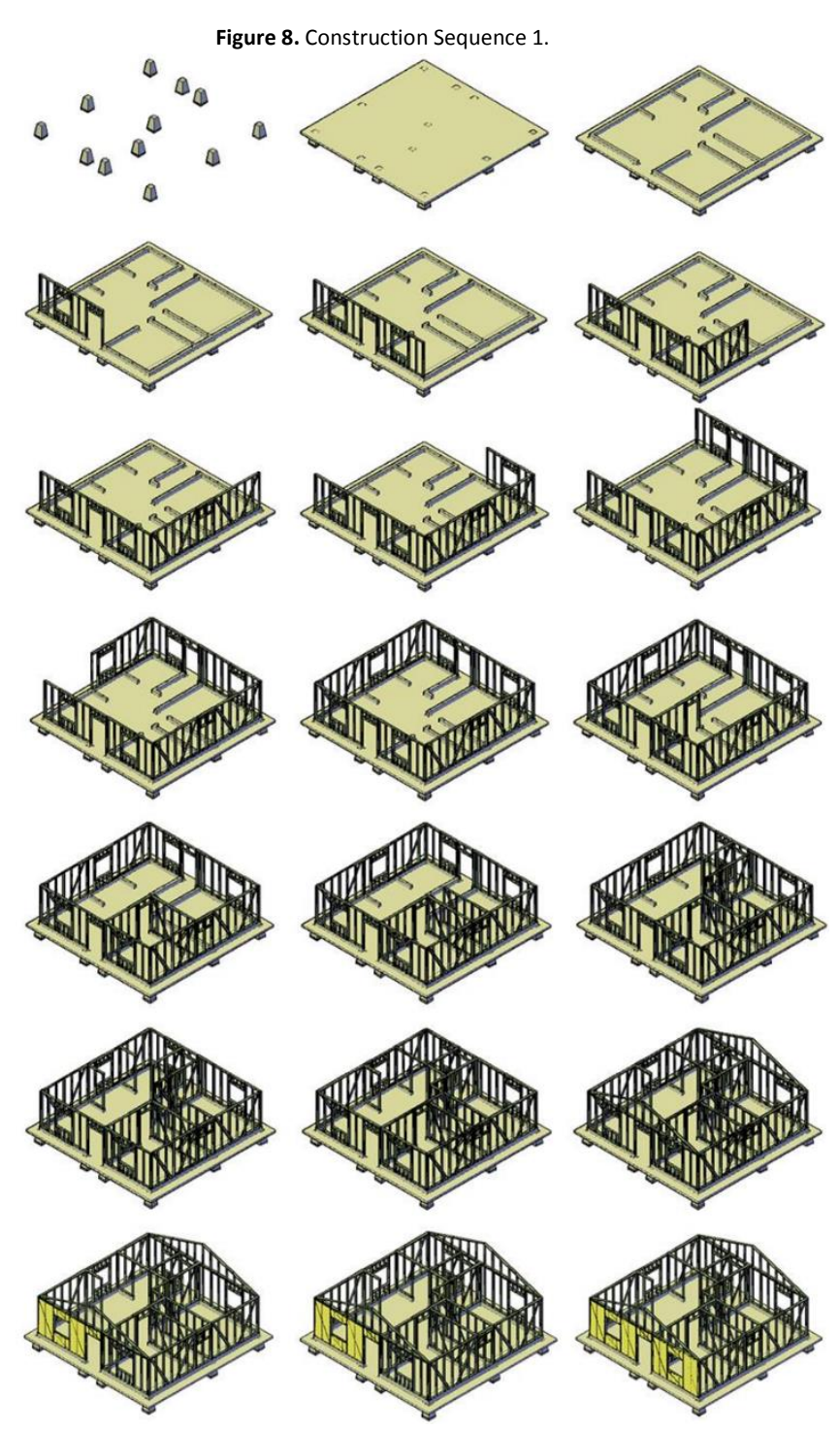


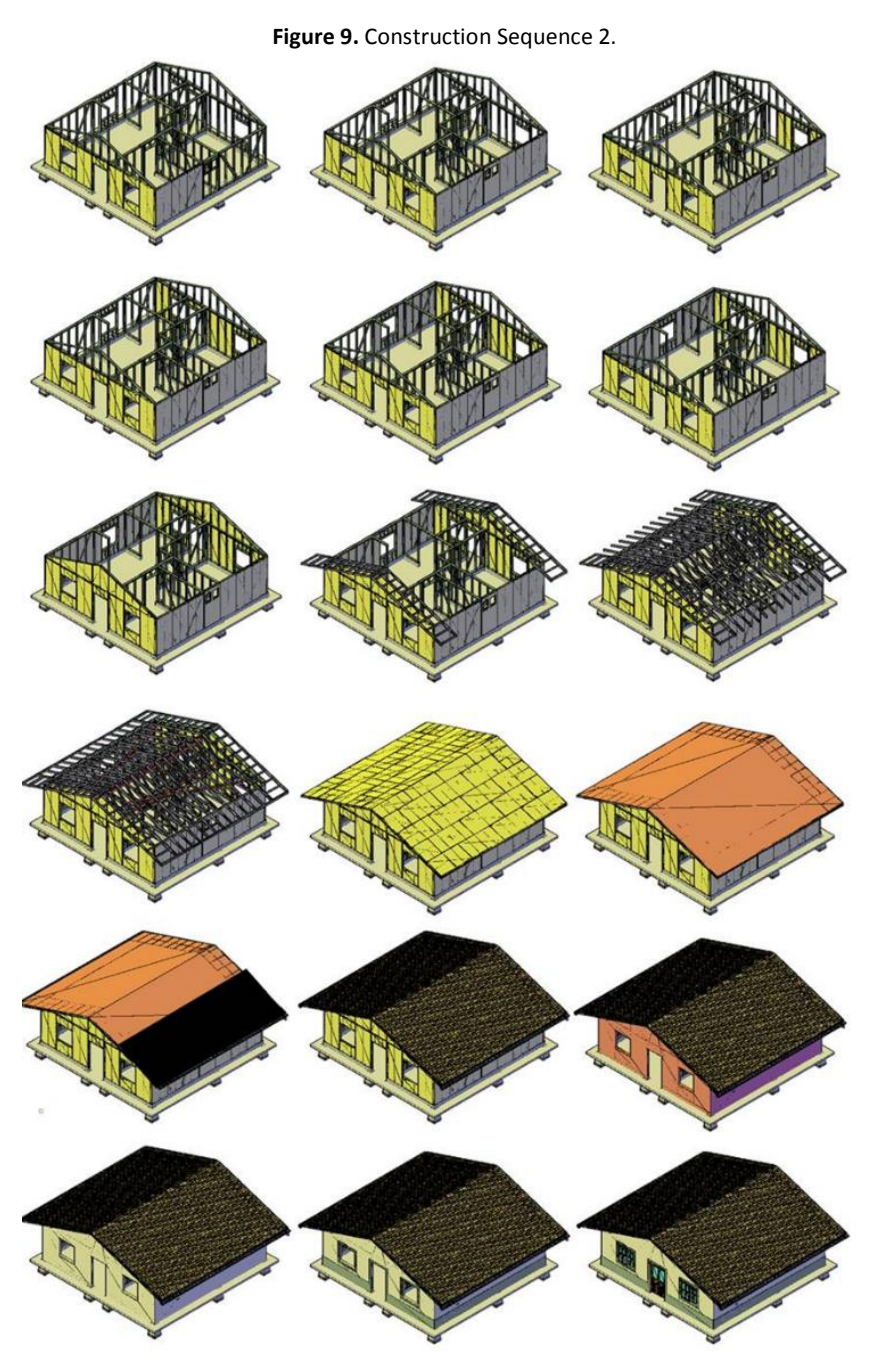

Conclusions

It is possible to correctly design a wood frame house on a step-by-step basis by following the recommendations and technical specifications found in regulations, standards and manuals; consequently, wood frame houses can be viewed as a practical alternative in home construction.

When carrying out a timber construction project, priority should be given to reviewing in detail all Mexican standards applicable to timber (ONNCCE), and subsequently relevant information such as regulations, complementary technical standards and construction manuals.

It was found that a wood frame house is light according to the calculated average unit weight of $0.15 \mathrm{t} / \mathrm{m}^{2}<4 \mathrm{t} / \mathrm{m}^{2} ; \mathrm{the}$ foregoing indicates that this value represents only $3.7 \%$ of the maximum limit for lightweight structures, according to the NTCRCDF (2004).

In Mexico, reforestation on a large scale should be encouraged to supply sufficient raw material to the wood frame construction sector.

Acknowledgements

The authors thank Mexico's National Science and Technology Council for funding the 2014-2016 scholarship. 
Ángeles, V. J. A. (2010). Prototipo de vivienda rural sustentable y confortable a base de materiales derivados de la madera y bagazo de coco. Tesis de Maestría, Escuela Superior de Ingeniería y Arquitectura, Instituto Politécnico Nacional, Ciudad de México, México.

Autodesk, Inc. AutoCAD 2010 "software”. Disponible en: www.autodesk.mx. Consultado el 30/04/2015.

Barajas, M. F.J. (2009). Proceso constructivo de una casa de madera como alternativa de construcción de casas habitación en México.Tesis de Licenciatura, Universidad Michoacana de San Nicolás de Hidalgo, Michoacán, México.

Comisión Forestal de América del Norte (COFAN). (1994). Manual de estructuras ligeras de madera1a. Edición. COMACO A.C., Ciudad de México, México.

Comisión Forestal de América del Norte (COFAN). (1999). Manual de estructuras ligeras de madera2a. Edición. COMACO A.C. y UACh., Ciudad de México, México.

Comisión Nacional Forestal (CONAFOR). (n.d.). Manual de Autoconstrucción de Vivienda con madera. Comisión Nacional Forestal. Consultado 31-032016 en http//www.conafor.gob.mx

Corporación Chilena de la Madera (CORMA). (2004). La construcción de viviendas en madera. s/e. Santiago, Chile.

Elizondo, B. J.E. 2009. La lluvia conducida por viento en las edificaciones. Tesis de Maestría, Escuela Superior de Ingeniería y Arquitectura, Instituto Politécnico Nacional, Ciudad de México, México.

Elorza, W. M. E. (1984). Actividades que se realizan para promover el uso de la madera en la construcción. Revista Ciencia Forestal, 49(9): 37- 4.

Colegio de Arquitectos del Estado de México, A.C. (2014). Curso-Taller: Diseño y Construcción con Madera (CT-DCM). Edo. de México, México.

Espinosa, Z. S., Fuentes, S. M., Santiago, T. O., Cornejo, O.E., Rivera, M.C.\& López, B.O. (2010). Secado de la madera aserrada. Fundación Produce Chiapas, A.C. Universidad Autónoma de Chiapas. Chiapas, México.

Filio, R. O. A. (2016). Proyecto de construcción de una casa de madera tipo. Tesis de Maestría, División de Ciencias Forestales, Universidad Autónoma Chapingo. Edo de México, México.

Facultad de Ingeniería en Tecnología de la Madera(FITECMA). (2011). Sistema constructivo Fitecma (México) 7(3): 3-19.

Flores, V. R. (2005). Competitividad de la cadena productiva de madera aserrada en México: el caso de la región Chignahuapan-Zacatlán, Puebla. Tesis de Doctorado, CIESTAAM, Universidad Autónoma Chapingo. Edo de México, México.

Hanono, B. M. (2005). Construcción en madera. Río Negro, Argentina: Editorial CIMA.

Inat S., T. (2011). Sistema de plataforma con entramado ligero de madera. Puesta en obra y aceptación en España. Tesis de Maestría, Universidad Politécnica de Cataluña, España.

Junta del Acuerdo de Cartagena (JUNAC). (1980). Cartilla de construcción con madera. Lima, Perú.

Junta del Acuerdo de Cartagena (JUNAC). (1988). Manual del grupo andino para la preservación de maderas. Lima, Perú. Editorial PRID-MADERA

NMX-C-239-ONNCCE-(1985). Clasificación visual para madera de pino de uso estructural. México.

NMX-C-410-ONNCCE-(1999). Industria de la construcción - Vivienda de madera - Retención y penetración de sustancias preservadoras en madera métodos de prueba, publicado en el Diario Oficial de la Federación, el día 17 de junio de 1999. México.

NMX-C-411-ONNCCE-(1999). Industria de la construcción - Vivienda de madera - Especificaciones de comportamiento para tableros a base de madera de uso estructural, publicado en el Diario Oficial de la Federación, el día 24 de noviembre de 1999. México.

NMX-C-224-ONNCCE-(2001). Industria de la construcción - Vivienda de madera y equipamiento urbano - Dimensiones de la madera aserrada para su uso en la construcción, publicado en el Diario Oficial de la Federación, el día 29 de enero de 2002. México.

NMX-C-439-ONNCCE-(2006). Industria de la construcción - Tableros contrachapados de madera de pino y otras coníferas - Propiedades físicas métodos de ensayo, publicado en el Diario Oficial de la Federación, el día 15 de diciembre de 2006. México.

NMX-C-440-ONNCCE-(2006). Industria de la construcción - Tableros de contrachapados de madera de pino y otras coníferas - Propiedades mecánicas - Métodos de ensayo, publicado en el Diario Oficial de la Federación, el día 15 de diciembre de 2006. México.

NMX-C-460-ONNCCE-(2009). Industria de la construcción - Aislamiento térmico - Valor " $R$ " para las envolventes de vivienda por zona térmica para la República Mexicana - Especificaciones y verificación, publicado en el Diario Oficial de la Federación, el día 18 de agosto de 2009. México.

NMX-C-178-ONNCCE-(2014). Industria de la construcción - Preservadores para madera - Clasificación y requisitos, publicado en el Diario Oficial de la Federación, el día 07 de noviembre de 2014. México.

NMX-C-322-ONNCCE-(2014). Industria de la construcción - Madera preservada a presión - Clasificación y requisitos, publicado en el Diario Oficial de la Federación, el día 07 de noviembre de 2014. México.

NMX-C-419-ONNCCE-(2014). Industria de la construcción - Preservación de maderas - Terminología, publicado en el Diario Oficial de la Federación, el día 01 de diciembre de 2014. México.

NMX-C-438-ONNCCE-(2014). Industria de la construcción - Tableros contrachapados de madera de pino y otras coníferas - Clasificación y especificaciones, publicado en el Diario Oficial de la Federación, el día 07 de noviembre de 2014. México.

Parker H. \& Ambrose J. (2012). Diseño simplificado de estructuras de madera. Traducción de la 2da Edición: Raúl Arrioja Juárez. México. Editorial Limusa Wiley. 
Secretaría de Obras y Servicios (NTCRCDF). (2004). Normas Técnicas Complementarias del Reglamento de Construcciones para el Distrito Federal. México.

Secretaría de Obras y Servicios (RCDF). (2004). Reglamento de Construcciones para el Distrito Federal. México

Sánchez, C. J. (2012). La vivienda "Social" en México: Pasado - presente - futuro?. México.

Sánchez, R. L. (2008). Diplomado en aprovechamiento, conservación y restauración de recursos forestales. Universidad Autónoma Chapingo. Edo de México. México.

Zamudio, S. E. (1986). Manual de la Industria Maderera. Serie Agronómica N¹0. Universidad Autónoma Chapingo. Edo de México, México. 